Innlegg på inntil $\mathbf{4 0 0}$ ord lastes opp i http://mc.manuscriptcentral.com/tidsskriftet.

Redaksjonen forbeholder seg retten til å foreta redaksjonelle endringer.

Forfattere av vitenskapelige artikler har automatisk tilsvarsrett (jf. Vancouver-gruppens regler).

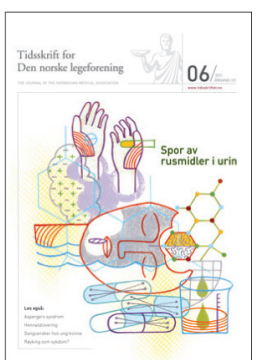

\section{Dystert om tobakk fra SIRUS}

I Tidsskriftet nr. 6/2011 hevder sosiolog Karl Erik Lund ved Statens institutt for rusmiddelforskning (SIRUS) at Norge ikke kan bli røykfritt med dagens metoder. Videre forkastes ideen om et tobakksfritt samfunn fordi visjonen vil «stå i veien for tiltak som kan redusere tobakksrelatert dødelighet» (1).

Lund forventer at den resterende «kjerne røykere» nærmest er resistent mot tradisjonell påvirkning og hjelp. Det dreier seg om 800000 dagligrøykere (2). Han foreslår markedsføring av snus og nikotinlegemidler, under forutsetning av at vi betrakter røyking «som en kronisk lidelse som trenger livslang medisinering» (1). Ideene stemmer overens med tobakksindustriens markedsstrategi og ble nærmere beskrevet i 2009 i en 80-siders rapport om «skadereduksjon» fra SIRUS (3).

I tobakksspørsmål vil vel de fleste tolke «skadereduksjon» som all reduksjon av bruken eller skadevirkningene av tobakk. Lunds definisjon er mer snever og ligger tett opptil det snusprodusentene kaller «harm reduction» eller «riskreduktion» (4). Med finansiering fra Helse- og omsorgsdepartementet og fra Norges forskningsråd har Statens institutt for rusmiddelforskning gjennom flere år formidlet tobakksindustriens strategiske tankegods, herunder anbefaling av snus ved røykeslutt, til tross for svært mangelfull dokumentasjon av effekt og bivirkninger.

Lunds dystre spådommer begrunnes med det han mener er en beskjeden nedgang $i$ det absolutte antall norske røykere siden 1960 (1). Han unnlater å nevne at folketallet samtidig har økt med 1,2 millioner. Jeg finner det naturlig å peke på at andelen dagligrøykere sank fra $32 \%$ til $21 \%$ fra 1999 til 2009 (2).

Lund antar at det vil gå 30-40 år før andelen røykere i Norge er nede på $10 \%$ og henviser til beregninger fra USA og Australia. Disse modellbaserte antakelsene serveres uten diskusjon av tilgrunnliggende forutsetninger eller overførbarhet.

Verdens helseorganisasjon anbefalte

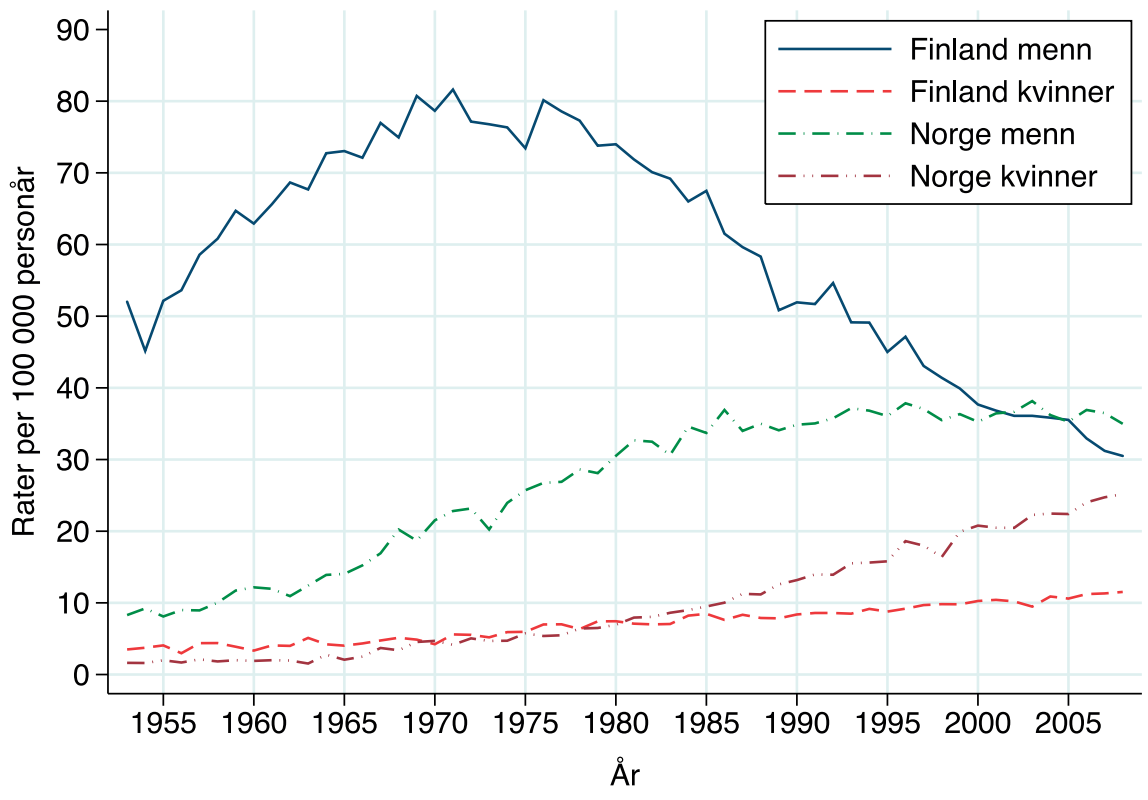

Figur 1 Forekomst av lungekreft i Finland og Norge, aldersjusterte rater. Tall fra Den nordiske kreftregisterforeningen (ANCR) (6), gjengitt med tillatelse i 2010 norske myndigheter å styrke arbeidet mot tobakk, inkludert økt innsats mot bruk av snus (5). Lunds torpedering av dagens visjoner og virkemidler står i grell kontrast til Finlands nye tobakkslov (2010), der målet ble definert i lovteksten: en tobakksfri nasjon. Finnene vil dessuten forby salg og privat import av snus. Hva Finland allerede har oppnådd med røykeslutt, hovedsakelig uten bruk av snus, illustreres av en formidabel nedgang i forekomsten av lungekreft hos menn (fig 1) (6).

\section{Tom K. Grimsrud}

tom.k.grimsrud@kreftregisteret.no

Oslo

Tom K. Grimsrud (f. 1955) er dr.med. og spesialist i arbeidsmedisin. Han er forsker ved Kreftregisteret, jobber med miljø-og yrkesrelaterte årsaker til kreft og er medlem av Nasjonalt råd for tobakksforebygging. Ingen oppgitte interessekonflikter.

\section{Litteratur}

1. Lund KE. Kan Norge bli røykfritt? Tidsskr Nor Legeforen 2011; 131: 563-4.

2. Helsedirektoratet. Tall om tobakk 1973-2009. Oslo: Helsedirektoratet, 2010. www. helsedirektoratet.no/publikasjoner/rapporter/ tall_om_tobakk_1973_2009_792024 (22.3.2011).

3. Lund KE. Tobakksfritt samfunn eller skadereduksjon? Hvilken målsetting tjener de gjenstående røykerne? SIRUS-rapport nr. 2/2009. Oslo: Statens institutt for rusmiddelforskning, 2009. www.sirus.no/filestore/Import_vedlegg/ sirusrap.2.09.pdf (22.3.2011).

4. Swedish Match. Läkare blir vetenskaplig rådgivare på Swedish Match. www.swedishmatch.com/sv/ Media/Pressmeddelanden/Press-releases/ Ovriga/Lakare-blir-vetenskaplig-radgivare-paSwedish-Match/ (7.3.2011).

5. Evaluering av arbeidet med tobakksforebygging i Norge. WHO-rapport. Oslo: Helse- og omsorgsdepartementet, 2010. www.regjeringen.no/ Upload/HOD/Dokumenter\%20FHA/Tobakk/ WHO rapport NORSK.pdf (22.3.2011).

6. Enghölm G, Férlay J, Christensen N et al. NORDCAN: Cancer incidence, mortality, prevalence and prediction in the Nordic countries, version 3.7. Association of the Nordic Cancer Registries. København: Danish Cancer Society, 2010. www.ancr.nu (24.3.2011)

\section{Betydningen av klinisk skjønn}

Geeta Gulati, Torstein Hole og Eigill Eide presenterer i Tidskriftet nr. 2/2011 en utmerket artikkel om infeksiøs endokarditt ved Ålesund sjukehus for årene 1997-2006 (1). Innholdet i min artikkel, som ble publi- 
sert for 40 år siden, er ikke tilsvarende lett tilgjengelig (2). Data fra undersøkelsene gir mulighet til vurdering av trender i et 45 års tidsperspektiv ved samme avdeling.

Den siste undersøkelsen er et tiårsmateriale som bare omfatter infeksiøs endokarditt. Min undersøkelse omfatter alle tilfeller av sepsis, med infeksiøs endokarditt som undergruppe i et femårsmateriale fra årene 1964-68. Relevante data fra endokardittmaterialet blir gjengitt her.

Hele sepsismaterialet utgjorde 51 pasienter, dvs. vel ti pasienter per år i snitt. Samlet mortalitet var $27 \%$ (2). Av de 51 fikk ti diagnosen endokarditt. Bare én av disse døde, dvs. 10\% mortalitet (2). Min undersøkelse ble planlagt i 1966 og var derfor både retrospektiv og prospektiv. Jeg mener den gir et pålitelig tidsbilde av hvordan denne pasientgruppen ble behandlet for over 40 år siden.

Kliniske data og sammensetning i de to undersøkelsene viser ikke store forskjeller, men insidensen ser ut til å ha økt fra to til 6,3 per år $(1,2)$. Mortaliteten var i mitt materiale $10 \%$, i det siste $16 \%$. Prinsippene for valg av antibiotika etter resistens og behandlingslengden var like. Dette viser at infeksjonsbehandling var godt etablert. Derimot var mulighetene for kardiologiske spesialundersøkelser sterkt begrenset. Transøsofageal ekkokardiografi hadde sannsynligvis ført til at noen i mitt materiale med klassifikasjonen sepsis ville ha fått diagnosen endokarditt. Det ville gitt økt årlig insidens og høyere mortalitet i mitt materiale. Men etter min mening ville det neppe gitt så store utslag at det ville ha svekket inntrykket av at insidensen av endokarditt har vært økende.

Det indremedisinske fagområdet har forandret seg enormt fra jeg var ferdig lege i 1960. Enkelte fra min generasjon og atskillig flere av de yngre har periodevis tendens til å nedvurdere det man kunne gjøre før 1970. Disse to undersøkelsene gir ikke grunnlag for en slik nedvurdering. Verdien av det tradisjonelle kliniske skjønnet på basis av gode kunnskaper og en fullstendig klinisk undersøkelse bør ikke avskrives.

\section{Odd Johan Frisvold}

ojofrisv@online.no

Ålesund

Ole Johan Frisvold (f. 1934) er spesialist i indremedisin og hjertesykdommer og er pensjonert avdelingsoverlege, Medisinsk avdeling og sjeflege Sentralsjukehuset i Møre og Romsdal. Ingen oppgitte interessekonflikter.

\footnotetext{
Litteratur

1. Gulati G, Hole T, Eide E. Infeksiøs endokarditt ved Ålesund sjukehus 1997-2006. Tidsskr Nor Legeforen 2011; 131: 115-7.

2. Frisvold OJ. Sepsis. Tidsskr Nor Lægeforen 1970; 90: $1697-700$
}

Hole og medarbeidere svarer:

Vi takker for interessen for vår artikkel. Ved litteraturs $\varnothing \mathrm{k}$ fant vi dessverre ingen referanse til Frisvolds artikkel (1), sannsynligvis fordi dette hovedsakelig er kategorisert som et sepsismateriale.

Den økte insidensen av infeksiøs endokarditt i vår studie (2) kan til en viss grad, som Frisvold påpeker, skyldes økt sensitivitet til å påvise vegetasjoner ved bruken av transøsofageal ekkokardiografi. Det er nærliggende å tro at de standardiserte Dukes' kriterer fra 1994 øker presiseringen av diagnostiseringen for infeksiøs endokarditt. Om insidensen er økende, er derfor vanskelig å si. Riktignok har vi i dag en mindre gruppe med revmatisk klaffelidelse i befolkningen, men pasientgruppen som rammes er blitt eldre, og agens er endret. Mange har også intravaskulære/intrakardiale implantater. Antibiotika brukes etter resistensmønster, og resistensmønsteret har endret seg. I Frisvolds artikkel var det kun $8 \%$ penicillinresistente gule stafylokokker i Norge, i dag er det ca. $80 \%$. Den gang ble streptomycin brukt hyppig, og antibiotika ble ofte gitt intramuskulært. Streptomycin og intramuskulær administrering er ute av den kliniske hverdagen i dag.

Mortaliteten i Frisvolds materiale var på $10 \%$, i vårt materiale var dette på $16 \%$. Det er usikkert om økt diagnostisering av infeksiøs endokarditt i Frisvolds materiale ville ført til økt mortalitet hos denne gruppen. I hans materiale hadde ni av ti med diagnosen endokarditt oppvekst av grampositive agens. I totalmaterialet hadde 25 av 51 pasienter oppvekst av grampositive agens, og av disse var det ti som hadde grønne streptokokker og sju som hadde gule stafylokokker. I vårt materiale var det overvekt av grampositive agens, hovedsakelig stafylokokker og da spesielt gule stafylokokker som er mer virulente enn streptokokker. Skifte av agens kan forklares av endret pasientgruppe, og endret agens kan også eventuelt forklare et mer virulent forløp.

Kunnskapen innenfor medisinen er under stadig utvikling, og hva som en gang ble ansett som riktig behandling kan i dag være kontraindisert ved samme sykdom. Vi er enige i verdien av det kliniske skjønn på basis av gode kunnskaper. En fullstendig klinisk undersøkelse bør ikke avskrives, men den bør kombineres med maksimal utnyttelse av moderne teknologi og nye kunnskaper.

\section{Torstein Hole}

torstein.hole@helse-sunnmore.no Geeta Gulati

Eigill Eide

Medisinsk avdeling

Ålesund sjukehus
Torstein Hole (f. 1957) er dr.med. og spesialist i indremedisin og i hjertesykdommer. Han er klinikksjef ved Medisinsk klinikk, Helse Sunnmøre og amanuensis II, Det medisinske fakultet, NTNU. Ingen oppgitte interessekonflikter.

Geeta Gulati (f. 1982) er cand.med., stipendiat, arbeidet ved Medisinsk avdeling, Ålesund sjukehus, er nå ved Akershus universitetssykehus. Ingen oppgitte interessekonflikter.

Eigill Eide (f. 1947) er spesialist i infeksjonssykdommer og er avdelingsoverlege, Medisinsk avdeling. Ingen oppgitte interessekonflikter.

Litteratur

1. Frisvold OJ. Sepsis. Tidsskr Nor Lægeforen 1970; 90: 1697-700

2. Gulati G, Hole T, Eide E. Infeksiøs endokarditt ved Ålesund sjukehus 1997-2006. Tidsskr Nor Legeforen 2011: 131: 115-7.

\section{RETTELSE}

Infeksiøs endokarditt ved Ålesund sjukehus 1997-2006.

Geeta Gulati, Torstein Hole, Eigill Eide

Tidsskr Nor Legeforen 2011; 131: 1154-7

I Tidsskriftet nr. 2, side 117, tabell 4: Enterobacter cloacae var feilaktig plassert i gruppen enterokokker, skulle vært plassert under gruppen Annet.

\section{Tilsvarsrett:}

Tidsskriftet praktiserer tilsvarsrett i henhold til Vancouver-gruppens regler (www.icmje.org/publishing 5 correspond.html).

Dette innebærer at forfattere av vitenskapelige artikler som blir kommentert i spalten Brev til redaktøren, får anledning til å komme med tilsvar i samme nummer av Tidsskriftet. Ytterligere innlegg vil bli henvist til et senere nummer. 